УДК 792.09

\author{
Вовкун Василь Володимирович, \\ кандидат культурології, доцент, \\ професор кафедри режисури \\ та акторської майстерності \\ Національної академії керівних кадрів \\ культури і мистецтва \\ ORCID 0000-0001-6800-5367
}

\title{
ФОЛК-ОПЕРА «КОЛИ ЦВІТЕ ПАПОРОТЬ» Є. СТАНКОВИЧА: ІСТОРІЯ ТА РЕЖИСЕРСЬКІ РЕФЛЕКСІЇ
}

\begin{abstract}
Метою роботи є аналіз особливостей постановки фолк-опери С. Станковича «Коли цвіте папороть» та основні режисерські підходи до постановки цього твору наприкінці XX на початку XXI століття. Методологія дослідження базується на міждисциплінарному підходів, який дозволяє використовувати здобутки історії культури, музикознавства, театрознавства, культурології та ін. У статті було використано ряд методів: порівняльний, який дозволив порівняти сценографію оригінальної вистави та іiі інтерпретації в Львівській національній опері; історичний допоміг проаналізувати соціально-політичні обставини за створювалася ця вистава; метод синтезу дозволив розкрити варіативність форм постановки опери С. Станковича. Науковою новизною дослідження є висвітлення трансформації сюжетно-композиційної специфіки фолк-опери «Коли цвіте папороть» Є. Станковича та ії сучасні режисерські інтерпретації на прикладі фолк-опери-балету «Коли цвіте папороть» Львівської національної опери. Висновки: Таким чином, незважаючи на складну долю постановки фолк-опери С. Станковича «Коли цвіте папороть», цей твір увійшов в історії української культури як зразок «нової фольклорної хвилі», який у XXI столітті переживає свій Ренесанс у формі різноманітних режисерських інтерпретацій, особливе місце серед яких займає постановка Львівської національної опери 2017 року, яка характеризується поєднанням просторово-часового вимірів рефлексії національної автентичної культури предків та сьогодення.
\end{abstract}

Ключові слова: папороть, феєрія, фолк-опера, лібрето, авангард, фольклор, сюжет, композиція, образ, трансформація, художня ідея.

Вовкун Василий Владимирович, кандидат культурологии, дочент, профессор кафедры режсисуры и актерского мастерства Нацииональной академии руководящих кадров культуры и искусства

Фолк-опера «Когда цветет папоротник» Е. Станковича: история и режиссерские рефлексии

Целью работы является анализ особенностей постановки фолк-оперы Е. Станковича «Когда цветет папоротник» и основные режиссерские подходы к постановке этого произведения в конце XX начале XXI века. Методология исследования базируется на междисциплинарные подходы, которые позволяют использовать достижения истории культуры, музыковедения, театроведения, культурологии и др. В статье были использованы ряд методов: сравнительный, который позволил сравнить сценографию оригинальной представления и ее интерпретации в Львовской национальной опере; исторический помог проанализировать социально-политические обстоятельства по создавалась этот спектакль; метод синтеза позволил раскрыть вариативность форм постановки оперы Е. Станковича. Научной новизной исследования является освещение трансформации сюжетно-композиционной специфики фолкоперы «Когда цветет папоротник» Е. Станковича и ее современные режиссерские интерпретации на примере фолкоперы-балета «Когда цветет папоротник» Львовской национальной оперы. Выводы: Таким образом, несмотря на сложную судьбу постановки фолк-оперы Е. Станковича «Когда цветет папоротник», это произведение вошел в истории украинской культуры как образец «новой фольклорной волны», который в XXI веке переживает свой Ренессанс в форме различных режиссерских интерпретаций, особое место среди которых занимает постановка Львовской национальной оперы 2017 года, которая характеризуется сочетанием пространственно-временного измерений рефлексии национальной аутентичной культуры предков и настоящее.

Ключевье слова: папоротник, феерия, фолк-опера, либретто, авангард, фольклор, сюжет, композиция, образ, трансформация, художественная идея.

Vovkun Vasyl, PhD in Cultural studies, professor of the Department of Directing and Actor's Mastering, National Academy of Culture and Arts Management

E. Stankovych's Folk-Opera «When the Fern Blooms»: history and director's reflections

Purpose of Research. The purpose of the article is to analyse the peculiarities of the production of E. Stankovych's folk opera «When the Fern Blooms» and the main directorial approaches to the production of this work at the end of the XX century the beginning of the XXI century. Methodology of Research. The methodology of the research is based on interdisciplinary approach, which allows us to use the achievements of the history of culture, musicology, theatrical studies, cultural studies, etc. The author has used the following methods: a comparative method (to compare the stage design of the original performance and its interpretation in the Lviv National Opera); a historical method (to analyse the socio-political circumstances of the creation of this folk-opera); a method of synthesis (to highlight the variability of the forms of staging of E. Stankovych's opera). Scientific

(C) Вовкун В.В., 2019 
Novelty. The scientific novelty of the research is the analysis of the transformation of the plot-composition specificity of the folk opera «When the Fern Blooms» by E. Stankovych and its contemporary directorial interpretations on the example of the folk opera-ballet «When the Fern Blooms» of the Lviv National Opera. Conclusions. Thus, despite the complex fate of the production of E. Stankovych's folk opera «When the Fern Blooms», this work entered the history of Ukrainian culture as an example of a «new folk wave». At the beginning of the XXI we can see its Renaissance in the forms of various directorial modifications, where the the staging of the Lviv National Opera 2017 occupies the special place among them. It is characterized by the combination of spatial-temporal dimensions of reflection of national authentic ancestral culture and the present one.

Key words: fern, extravaganza, folk opera, libretto, avant-garde, folklore, plot composition, image, transformation, artistic idea.

Актуальність. Сучасний мистецький простір характеризується синергетикою жанрів, варіативністю форм постановок та символізмом, які $є$ наслідком еволюції національного театрального музичного мистецтва другої половини ХХ століття. Сорок років тому в 1979 році мала відбутися прем'єра одного 3 найграндіозніших проектів національної сценічного мистецтва - фолк-опери С. Станковича «Коли цвіте папороть», яка синтезувала в собі зразки минулого та сучасного. Сьогодні здійснюються спроби реабілітації цього видатного твору різними театрами, серед яких Львівська національна опера імені Соломії Крушельницької, тому рефлексія нової та оригінальної постановки слугуватимуть систематизації символізму та режисерських ідей нової та старої генерації.

Аналіз останніх досліджень: Постановка фолк-опери «Коли цвіте папороть» Є. Станковича виступала предметом аналізу різноманітних міждисциплінарних досліджень українських науковців. Зокрема, особливості їі хореографічної постановки 1970-х років розкриваються у статтях Л. Маркевич [3] та В. Щербакова [9]. 3 точки зору музикознавства цю оперу аналізував у своїх наукових публікаціях доктор мистецтвознавства, компаративіст Ю. Чекан [6,7], який проводить паралелі між розвитком українського «романтичного» кінематографу та Ренесансом академічної музики у другій половині ХХ століття. Українська дослідниця, музикознавець Л. Шевчук-Назар здійснює аналіз сучасної інтерпретації легендарного твору С. Станковича у Львівській національній опері у контексті тенденцій синтезу жанрів у світовому музичному просторі [8]. Найгрунтовнішим дослідженням, яке присвячене цьому твору $є$ дисертаційна робота, Р. Стакович-Спольської ««Цвіт папороті» С. Станковича: проблема жанру» у якій проаналізовано жанрову-стильову специфіку музичного театру у другій половині ХХ століття, а також особливості неофолклоризму в українському сценічному мистецтві [5]. Режисерський підхід до аналізу оперних постановок частково розкрито у наукових публікація А. Солов'яненка [4] та О. Ізваріної [2], однак наукова рефлексія постановки «Коли цвіте папороть» потребує глибшого аналізу, що й обумовлює актуальність нашого дослідження.

Метою статті є аналіз особливостей постановки фолк-опери С. Станковича «Коли цвіте папороть» та основні режисерські підходи до постановки цього твору наприкінці XX на початку XXI століття

Основна частина. Під час підготовки Радянського Союзу до участі в міжнародній виставці в Парижі, молодому українському композитору запропонували написати твір для великої сценічної постановки, що втілювала у собі синергетику народного та класичного мистецтва. Результатом стала поява у 1977 році напівлегендарної фолк-опери «Коли цвіте папороть», яка являла собою союз сучасних мистецьких тенденцій та традицій академічної музики. Вона об'єднала навколо себе таких представників українського мистецтва як композитор С. Станкович, музикознавець О. Стельмашенко, балетмейстер А. Шекера, диригента А. Авдієвського, художника Є. Лисика та інші.

У своєму дисертаційному дослідженні Р. Станкович-Спольська характеризуючи цей твір називає його зразком «нової фольклорної хвилі», що полягає ставленні композитора до народних звичаїв «коли прадавні народні мелодії чи інтонаційні тембри поєднуються в авторських творах 3 модерними принципами композиторської техніки»[5].

У своїх мемуарах Свген Станкович, зазначав, що «для нього як молодого композитора, постановка його твору була великим святом» [5]. Вражаючі автентичні костюми, декорації були розроблені для генеральної репетиції. Композитор підкреслював, що цей спектакль був унікальним явищем 3 прекрасними хорами та віртуозною хореографією, а також згадував слова Євгена Лисика: «Ти знаєш, мені здається, що при нашому житті ця опера ніколи поставлена не буде»[7]. Не зважаючи, на перипетії театральної долі спектаклю, сьогодні цей твір отримав нове життя на сцені Львівського оперного театру.

Заслужений художник України, О. Зінченко у своїх спогадах описує враження від спектаклю декорації описує елементи унікальної сценографії постановки, яка складалася з зміни чотирьох пір року залежно від емоційного стану головних героїв. На авансцені були розташовані три дерева-стовпи, верхівки яких прикрашали гнізда лелек. Барвисті костюми з елементами українського традиційного 
вбрання втілювали у собі земний світ. Незважаючи на високий художній рівень партійна комісія заборонила декорації, і вони залишилися лише в ескізах [5].

Народний художник України Тадей Риндзак входив до групи художників, які розробляли сценографію спектаклю, у своєму інтерв'ю присвяченому постановці «Коли цвіте папороть» Львівському національному академічному театрі опери та балету ім. С. Крушельницької, зауважував, що в 1978 році він був запрошений Є. Лисиком долучитися до роботи над концепцією сценографії фолк-опери «Коли цвіте папороть». Вони з братом їдуть до Києва, де представляють працюють протягом трьох місяців над декораціями. Під час генеральної репетиції комісія розкритикувала всю сценографію в результаті чого декорації були знищені. Пройшло понад десять років, коли Є. Лисик повернувся до своїх ескізів. Один $з$ них, осіння пора року, була доповнена мотивами козацьких переказів та використовується у спектаклях Львівської національної опери до цього часу [5].

Режисер, заслужений діяч культури Польщі Збігнєв Хшановський у своєму інтерв’ю присвяченого постановці «Коли цвіте папороть» у Львівському національному академічному театрі опери та балету ім. С. Крушельницької, згадував, що у 1970-х роках він багато працював у музичній редакції Львівського телебачення як режисер телевізійних версій оперних постановок. Одного разу його колега Є. Лисик розповідав про великий проект, над яким працював в Києві зі знаменитим Народним хором імені Григорія Верьовки і запросив його приєднатися до проекту як режисера до групи за згодою його творців Є. Станковича, А. Авдієвського та А. Шекери. Жанр майбутньої постановки був фолк-опера. В основі постановки лежали народні обряди та звичаї українського народу у різні пори року, які були втілені на чотирьох величезних горизонтах Є. Лисика, які написали Тадей і Михайло Риндзаки для великої сцени Палацу «Україна». Одним з головних питань постановки була озвучення спектаклю, тобто поставало питання створення фонограми або виконувати всі партії живим звуком. На жаль, спектакль так не побачила велика аудиторія, а сценографію та концепцію знищили [8].

Народна артистка України, Елеонора Стебляк, дружина балетмейстера А. Шекери бачила постановку 1978 року, хоровий спів, автентичні костюми, незвичайна хореографія - все це результат складної та грунтовної роботи з фольклорними джерелами, етнографічними дослідженнями композитора, художника, балетмейстера, режисера та всіх творчої групи. Особливе місце займає хореографія А. Шекери, який поєднав техніку класичного балету з елементами народної хореографії, створивши унікальні хореографічні композиції як козацький гопак (ігрища) та танець русалок, які були переповнені містикою та народними віруваннями. Сценографія Є. Лисика з порами року, трансформацією квітучого літнього вінка, що втілював щастя у зимовий терновий - образ смутку та горя, вирізнявся своєю художньою наповненістю та метафоричністю [5].

Протягом понад 30 років фолк-опера Євгена Станковича «Цвіт папороті» залишалася нереалізованою на сцені. Здійснювалося ряд спроб втілити їі фрагментарно на сценах українських театрів. Після отримання незалежності в Україні скалилася сприятливі умови для реалізації цього проекту, однак всі вони потерпали краху. Перша концепція постановки цього твору передбачала відкритий простір, тобто декораціями мали слугувати природні ландшафти навколо сцени - вода, живий вогонь, велика масовка у традиційних українських костюмах. Цей проект мав бути втілений за підтримки Віце-прем'єр-міністра України з гуманітарних питань М. Жулинського, однак на початковій стадії постановка призупинилась.

Друга концепція постановки, розроблена художниками Х. Широм та Т. Бірве передбачала втілення цього твору на великій концертній сцені під час Міжнародної виставки в 1998 році. [7]

Третя концепція постановки для оперного театру була створена та адаптована композитором на замовлення В. Василенка для Донецького оперного театру, однак глядач не побачив твору. а можливість реалізації цієї роботи...»

Четверта концепція постановки була розроблена для концертної сцени і втілена у життя Національним симфонічним оркестром України та Народним хором імені Г. Верьовки у 2011 році.

Нарешті п’ята концепція постановки фолк-опери-балету Є. Станковича «Коли цвіте папороть» стала складовою творчої програми Львівської національної опери «Український прорив». Над цією постановкою знову об'єднали свої сили автори оригінального спектаклю художник Є. Лисик та композитор Є. Станкович. Зважаючи на соціально-політичні та культурні процеси вони надали постановці нового дихання, що втілила у собі постфольклор, музично-сценічні технології, естетику авангарду та сучасну хореографію.

Український музикознавець Ю. Чекан у своїй статті «П’ять поглядів на «Цвіт папороті» відзначає відсутність лінійного сюжету у постановці, що являє собою своєрідну мозаїку в якій переплітаються епізоди життя українців, їх вірувань, обрядів та звичаїв. На думку дослідника, така постановка 
перегукується своїми образами та метафорами з українським поетичним кіно другої половини ХX століття. [7]

Варто зауважити, що постановка Львівського оперного театру суттєво відрізняється від оригінального сюжету композиції. Для створення цілісності твору та його актуалізації до сьогодення $Є$. Станкович на прохання творчої групи театру адаптував музику до режисерської версії «Коли цвіте папороть».

Отже, постановка складається $з$ двох дій. Перша дія втілює у собі «природній стан людини» або «золоту добу» за Ж.-Ж. Руссо, коли люди не знали несправедливості, горя, нерівності і жили в гармонії 3 природою. Анімізм охоплював всі сфери людського буття, дерева, ріки, квіти - всі виступали суб'єктами існування людини. Фабула побудована навколо свята Івана Купала і представлена різноманітними хореографічними композиціями Сонцекрес, «Русалчині Купала», «Відьомські Купала» та «Цвітіння папороті», остання розкривається у дуалізмі квітки та кохання. Аналізуючи постановку Львівської національної опери український музикознавець Л. Шевчук-Назар наголошує на важливості образу «Дерева Життя», яке є центральним елементом сценографії першої дії. Саме навколо нього ми спостерігаємо купальські хороводи людей, русалії та гуляння молоді, яка шукає таємничу квітку. 3 кожним епізодом «Дерево Життя набирає неймовірних кольорів - буйна зелень, величне сонячне проміння заливає багатством барв всерозмаїття світу, аж переповнюючи землю вщерть теплом, плідністю, щедрістю, висвічуваними з глибин неземними кольорами квітки щастя...» [8].

Друга дія повертає глядача до реального жорстокого світу, що переповнений людськими стражданнями, катастрофами та втратами, викликаючи у нас асоціативною ряд 3 козацькою Руїною та втратою державності. Основними епізодами другої дії є танець чаклунок на чолі з Війною, Образ козака, який бореться з життєвими перешкодами на шляху до свого ідеалу щастя - чарівної квітки, що дарує спокій, гармонію та любов [8].

Центральним героєм постановки $є$ народ, який зображений в узагальнюючому образі, що наповнений ідеалами, уявленнями, віруваннями людей. Сюжет розкривається у двох вимірах часовому та просторовому. Перший проявляється у лінійній та циклічній формах. Лінійна форма полягає у взаємозв'язку двох дій опери-балету - так званому переході від гармонійності, феміністичного начала природи до маскулійності війни, зброї та хаосу. Циклічність часу втілюється на сцені ситуаційними дублями та повторами. Простір розкривається у формі трьох рівнів світу: перший рівень (потойбічне життя) - це підлога, яка протягом спектаклю переповнена образами містичних сил (сцена 3 танком русалок); другий рівень (людський світ) - це безпосередньо сцена, де відбуваються дії та розташований хор та третій рівень (небесний світ) - це великий екран, що виступає полотном на фоні якого відбуваються події та сходить сонце. Таким чином, спектаклю являє собою цілісний ідеалістичнообразний хронотоп української національної культури.

Такий організаційний задум дві рефлексії минулої і сьогоднішньої постановки, адже до проекту запрошено художника-сценографа Тадея Риндзака, учня Є. Лисика, солістка Ніна Матвієнко для голосу якої писалися арії до фолк-опери, художник по костюмах Галина Іпатьєва, яка один рік теж вчилася у Є. Лисика. Варто зауважити, що постановка присвячується пам'яті Євгена Микитовича Лисика. 3 молодшого покоління до постановочної групи увійшли балетмейстери Артем Шошин і Сергій Наєнко, художник по світлу та відео-інсталяції Дмитро Ципердюк, диригенти Володимира Сіренко та Юрій Бервецький.

Науковою новизною дослідження є висвітлення трансформації сюжетно-композиційної специфіки фолк-опери «Коли цвіте папороть» Є. Станковича та іï сучасні режисерські інтерпретації на прикладі фолк-опери-балету «Коли цвіте папороть» Львівської національної опери.

Висновки: Таким чином, незважаючи на складну долю постановки фолк-опери С. Станковича «Коли цвіте папороть», цей твір увійшов в історії української культури як зразок «нової фольклорної хвилі», який у XXI столітті переживає свій Ренесанс у формі різноманітних режисерських інтерпретацій, особливе місце серед яких займає постановка Львівської національної опери 2017 року, яка характеризується поєднанням просторово-часового вимірів рефлексії національної автентичної культури предків та сьогодення.

\section{Jimepamypa}

1. Денисюк Ж. 3. Постфольклор як предмет гуманітарних досліджень: до постановки питання // Вісник Національної академії керівних кадрів культури і мистецтв: науковий журнал, 2016. № 2. С. 19-23.

2. Ізваріна О. М. Оперна режисура в українському музичному театрі 20 -х років XX століття // Музичне мистецтво в освітологічному дискурсі: [зб. наук. праць], 2018, № 3. С. 66-70. 
3. Маркевич Л. А. До питання модернізації художньої мови балетних вистав 60-80 років ХХ століття. // Українська культура: минуле, сучасне, шляхи розвитку: [зб. наук. праць], 2018. Вип. 26. С. 75 - 84.

4. Солов'яненко А. Оперна режисура у сучасних наукових дослідженнях. // Проблеми взаємодії мистецтва, педагогіки та теорії і практики освіти, 2012. Вип. 34. С. 370-378

5. Станкович-Спольська Р. «Цвіт папороті» Євгена Станковича: проблема жанру: автореферат дис. дослідження на здоб. наук. ступ. кандидата мистецтвознавства за спеціальністю 17.00 .03 - Музичне мистецтво. Київ: Національної музичної академії України імені П.І.Чайковського, 2005. 21 с.

6. Чекан Ю. Образ світу в музиці: від метафори до категорії // Історія музики в минулому і сучасності: науковий вісник НМАУ ім. П.І.Чайковського, 2000. Вип. 12. С. 221-228.

7. Чекан Ю. П’ять поглядів на «Цвіт папороті» // Moderato, 8 січня 2018 URL: http://moderato.in.ua/events/p-yat-poglyadiv-na-tsvit-paporoti.html (з екрану 03.12.2019 p.)

8. Шевчук-Назар Л. Новородження фольк-опери Євгена Станковича «Коли цвіте папороть» у Львові. Львів, 2018. URL https://opera.lviv.ua/novorodzhennya-folk-opery-yevgena-stankovycha-koly-tsvite-paporot-u-lvovi/ (з екрану 02.12.2019)

9. Щербаков В. В. Хореографічні рефлексії творів українських композиторів (В. Губаренка, М. Скорика та Є. Станковича) у постановках А. Шекери та Р. Поклітару // Мистецтвознавчі записки: [зб. наук. праць], 2018. Вип. 33. С. С. $102-109$.

\section{References}

1. Denisyuk, Z. (2016). Postfolklore as a subject of humanitarian research: regarding the issue. Visnyk Nationalnoi Academii of Kerivnyh kadriv kultury i mystectv, 2. 19-23 [in Ukrainian].

2. Izvarina, O. M. (2018). Opera Directing in the Ukrainian Musical Theatre of the 1920s. Myzychne mystectvo v osvitianskomu dyskursi, 3, 66-70 [in Ukrainian].

3. Markevych, L. A. (2018). On the Issue of the Modernization of the Artistic Language of Ballet Performances 60-80 years of the Twentieth Century. Ukrainska kultura: mynule, teperishne, shlyahy rozvytku, 26, 75 - 84 [in Ukrainian].

4. Solovyanenko, A. (2012). Opera Directing in Modern Scientific Research. Problemy Vzaemodii mizh mystectvom, padagogikou, teorieu ta praktykoiu osvity, 34. P. 370-378 [in Ukrainian].

5. Stankovych-Spolska, R. (2005). «The fern blossom» by Eugene Stankovych: the problem of genres. Extended abstract of the candidate's thesis. Kyiv [in Ukrainian].

6. Chekan, Y. (2000). The Image of the World in Music: from Metaphor to Category. Istoria muzyky mynule i teperishne, Bulletin of the National Music Academy of Ukraine, 12, 221-228 [in Ukrainian].

7. Chekan, Y. (2018). Five Views on «When the Fern Blooms». Moderato. Retrieved fromhttp://moderato.in.ua/events/p-yat-poglyadiv-na-tsvit-paporoti.html [in Ukrainian].

8. Shevchuk-Nazar L. (2018). Newborn of Yevhen Stankovych's folk-opera «When the Fern blooms» in Lviv. Lviv. Retrieved from https://opera.lviv.ua/novorodzhennya-folk-opery-yevgena-stankovycha-koly-tsvite-paporot-ulvovi/ [in Ukrainian].

9. Shcherbakov, V.V. (2018). Choreographic Reflections of the Works of Ukrainian Composers (V. Gubarenko, M. Skorik, and E. Stankovych). Mystectvoznavchi zapysky, 33, 102 - 109 [in Ukrainian].

Стаття надійшла до редакиії 21.06.2019 p. 